Nina M. Korać

Archaeological Institute, Belgrade

korac.nina@gmail.com
UDK 902.2:616.71-002-091.5(497.11)

Original research article

Received: June 04, 2010

Accepted: August 02, 2010

\title{
TWO CASES OF UNSPECIFIC INFECTIONS FROM VIMINACIUM
}

\begin{abstract}
In this paper, two tibiae from two skeletons discovered at the "Više grobalja" necopolis of the ancient Roman city of Viminacium, were compared and analyzed. Sex, age and individual height were studied. According to paleopathological analyses, it was observed that both skeletons showed traces of unspecific infections.

With macroscopic observation of the cross-section of paleopathological finds, an infection of the periostitis type was confirmed and by comparing both skeletons, direct cause of death (causa mortis) was studied.

KEY WORDS: VIMINACIUM, ROMAN NECROPOLIS, ARCHAEOLOGY, BIO-PHYSICAL ANTHROPOLOGY, PALEOPATHOLOGY, PALEOPATHOLOGICAL DIAGNOSIS, PERIOSTITIS, OSTEOMYELITIS.
\end{abstract}

\section{INTRODUCTION}

One of the biggest Viminacium cemeteries is named "Više grobalja" (the name was given according to modern cadastre units). The cemetery is situated $700 \mathrm{~m}$ to the southwest from the military camp, with common skeletal burials positioned northwest - southeast. The terrain falls in this direction, with denivellation of $2 \mathrm{~m}$. The area of the cemetery is some $450 \mathrm{~m}$ long and 80 to $100 \mathrm{~m}$ wide. It is interesting to mention that in the second half of 6th century, in the northwestern part of this cemetery, a Gepide cemetery was unearthed (Zotović and Jordović 1990). This cemetery was systematically excavated during the seventies, the eighties and at the beginning of the nineties of 20th century (Korać and Golubović, 2009). During these investigations, more than 3000 inhumations were discovered. The number of cremations was much smaller. Paleopathological observations of cremated remains are difficult and become more difficult if the remains are not well-preserved, so that they are actually very rare. But, when skeletal remains are concerned, paleopathology shows its real sense and meaning, in anthropological as well as in archaeological interpretation of the cemetery i. e. of the population which used this cemetery during a specific period of time.

* The article results from the project: Viminacium, Roman city and military legion camp - research of material and non material of inhabitants by using the modern technologies of remote detection, geophysics, GIS, digitalisation and $3 D$ visualisation (no 47018), funded by Ministry of Education and Science of the Republic of Serbia. 
Since skeletal remains from the Viminacium cemetery "Više grobalja" from the previous excavations have been preserved, two cases of unspecific infections have been studies for this occassion. These are the skeletons from graves G-90 and G-2112.

\section{MATERIAL}

At the "Više grobalja" cemetery, in soundage no. 6 , at the relative depth of $2.50 \mathrm{~m}$ a skeleton was discovered in a pit with no construction. It was orientated north - south, with a deviation of $20^{\circ}$ of the northern end towards the west. The deceised was placed on his right side. Legs are crouched and positioned to the height of his stomach. Arms are bent and the hands are placed under the chin. It should be mentioned that this inhumation is placed under an area with animal bones at the southern end of the slope. The youngest coins are the ones of Alexander Severus (Zotović and Jordović 1990).

In grave G-90 a skeleton of a young man was discovered, whose growth and development were not completed. His fragility is especially noticeable in the post-cranial part. The skull is poorly and incompletely preserved, but it was noticed that the sutura metopica was not ossified during the first few years of life, but was only partially present from bregmae to nasion. Of course, this was just a notified anatomic variation (Hauser and De Stefano 1989).

A for other bio-anthropological data about this skeleton, one should point out that no epiphysis of long bones were ossified, neither on distal nor on proximal part. Further on, no third mollars errupted on neither of the sides. It errupted in the maxilla, but its height did not reach the height of the neighbouring second molar. Because of these facts, his age was estimated from 15 to 20 years (Ferembach, Schwidetzky and Stloukal 1979).

According to regression tables concerning relationships between long bones and body height, average individual height could have been estimated. It is average because the greatest femur length was reconstructed and it was about $400 \mathrm{~mm}$.

It occurs that individual height was not more than $160 \mathrm{~cm}$ (Breitinger 1934).
Grave G-2112 was found in soundage 149 and within it, four male skeletons were discovered, whose individaul biological age, according to the same methodology applied in the previous case, were aged between 30 and 40. It is a mass inhumation of four individuals. The individuals were marked A, B, C and D. The deceased marked as D was orientated west-east, with the deviation of $15^{\circ}$ of the western part towards the south. It lies on its back in a stretched position, with arms stretched next to the body. The length of the skeleton measures $1,45 \mathrm{~m}$. The bones are poorly preserved. The skeleton is marked 2112/D and it was incompletely preserved even during the excavation. Therefore, no anthropological measures could have been gained, except for the tibia, on which a paleopathological change was noticed. Its length was calculated according to methodological principles of Martin and Saller an it measures $340 \mathrm{~mm}$ (Martin and Saller 1957). Accordign to the already mentioned regression tables, the individual height measured about $168 \mathrm{~cm}$.

Repeatedly, on skeletons from G-90 and G-2112/D of the "Više grobalja" cemetery, paleopathological changes were noticed on one tibia and they will be the subejcts of this paleopathological analysis.

\section{METHOD}

On skeletons put at disposal, sex was determined according to 21 morphological elements on skull and post-cranial skeleton. These include the following gender-morphological elements: tuber frontale et parietale, glabela-arcus supercilialis, processus mastoideus, protuberantia occipitalis externa, squama occipitalis, arcus supercilialis, arcus zygomaticus, facies malaris, corpus mandibulae, trigonum mentale, angulus mandibulae, capitulum mandibulae, angulus, pubis, pelvis major, pelvis minor, foramen obturatorium, incisura ischiadica major, sacrum, caput femoris, linea asperaena femurima, clavicula (Ferembach, Schwidetzky and Stloukal 1979). For determining age between $14 / 15$ and $21 / 23$ years of age diagrams according to Wolf-Heidegger were applied (WolfHeidegger 1954). With adult individuals, whose ossifzing of long bones was completed, as well as 
the process of erruption of permanent teeth, age was determined according to a complex method and based on the following elements: obliteration degree of skull sutturae, density degree of spongiose mass in the humerus head, density degree of spongiose mass in the femur head, surface relief of pelvis simphysis and the abrasion degree of molar teeth in both jaws (Ferembach, Schwidetzky and Stloukal 1980).

For calculating individual height, regression tables for males of E. Breitinger were used, which should correspond most to the European population of ancient times.

Paleopathological method is macroscopic and includes five cross-sections of the infected bone, which is illustrated. Actually, Fig. 1represents the tibia from garve no. 90, while Figs.2,3 and 4 illustrate the tibia from the grave no. 2112.

Since one is dealing with unspecific infectious bone diseases i.e about two cases of periostitis, their descriptions are anmed at Steinbock's (Steinbock 1976), Aufderheide's and RodriguezMartin's (Aufderheide and Rodriguez-Martin 1998), Ortner's (Ortner 2003), Hošovski and Mikić (Hošovski and Mikić 1995 ), Lovričević and Mikić (Lovričević and Mikić 1989)

\section{RESULTS}

Within the individual grave no. G-90, a skeleton of a young man was discovered, with light corporal structure and height of about $160 \mathrm{~cm}$. On this skeleton, the following palopathological find was observed: on one tibia, there is a change caused by an unspecific infection of bone tissues. The other tibia is healthy. Other palopathological changes were not noticed.

The change is placed on the periost, consumes the whole bone, it is of grey-brown color, porose, with slightly increased and clearly defined edges. Its appeanace resembles tree bark (see Fig. 1). Such a change indicates periostitis. It can be caused by different factors, ike unspecific bacterial infections, specific contageous diseases liki syphilis, trauma, metabolic diseases, venous insufficientions etc. It can be observed in two forms, in a local and in a general one, but it can also be observed from the aspect of acute or chonic periotitis. Contrary to osteotytis and osteomielitis, which are dangerous infections and could cause serious damages and even death, periostitis usually does not cause serious complications nor death, excep when it appears in a general, acute form. This individual did not survive the infection and died because of it before the age of twenty .

In the mass grave G-2112, four male individuals were discovered, aged between 30 and 40 years. On one of the individuals, marked as D, a tibia remained well preserved, although in general, the skeleton was poorly preserved and could offer no anthropological measures. The individaul height was estimated to about $168 \mathrm{~cm}$. At the preserved tibia, the following paleopathological find was observed: on the medial third of the diaphysis there is a limited and clearly defined change, with increased edges, of round shape and grey-brown colour. In order to gain a more detailed paleopathological find of this change, five cross-sections were made. During macroscopic observation of these cross-sections, it was noticed that there is a zadebljanje on the bone, similar to ivory and which spreads from the edge of the bone to the medullary canal. Medullary canal was not damaged. Changes of nidus type were noticed neither, indicating that one is not dealing with the infection of osteomyelitis type (see Figs. 2, 3, 4).

Such a find indicated periostitis of local type, since the individual survived this infection. It is usually a consequence of a trauma or chronic boils.

\section{DISCUSSION AND CONCLUSION}

For this paper, two cases of unspecific infections from ancient Viminacium were chosen. It turned out that they were cases of periostitis of different types (see Figs. 1-4).

The first case, connected to a younger individual, according to author's opinión was determined as general periostitis, also shown within the here presented documentation. The individual (skeleton no. 90), a male aged between 15 and 20, did not develop defensive mechanisms and did not conquer this infection, directly shown by his early death. So one could presume that with this individual, the disease was acute. We therefore 
conclude that for this individual, general periostitis was the direct causa mortis.

Among numerous ostheological reamins from ancient Viminacium, on which paleopathological changes of bone tissues are noticeable, as a case diamteral to the previously mentioned one, a deffect on tibia was observed on an individual from the mass grave G-2112. This individual marked as $\mathrm{D}$, was also male, forty years of age, which is above the average life length of Viminacium of that time (Hošovski and Mikić 1995).

As the paleopathological analysis showed, this individual suffered from local periostitis, shown on fotographs.

The goal of this paper is to show on actual finds from a single site, in this case Viminacium, that the same type of unspecific infections can be manifested differently. This manifestation can be of different result, also shown on this material. Still, the question remained opened whether resistance to this infection, as well as its result, could have been infuenced by individual age, or whether course of the disease could have been infuenced by some other factors, like health care, factors leading to the infection, social status etc. We presume that this question can hardly be answered precisely.

\section{LITERATURE}

Aufderheide, A.C. and Rodriguez-Martin, C. 1998

The Cambridge Encyclopedia of Human Paleopathology, Cambrigde: Cambridge University Press.

\section{Breitinger, E. 1938,}

Zur Berechnung der Körperhöhe aus den Langen Gliedmaßenknochen, Anthropologischer Anzeiger XIV (1938): 249-274.

Ferembach, D. Schwidetzky, I. and Stloukal, M. 1979, Empfehlungen für die Alters-und Geschlechtsdiagnose am Skelett, HOMO, 30/2 (1979): 1-32.
Ferembach, D. Schwidetzky, I. and Stloukal, M. 1980,

Recommendation for Age and Sex Diagnosis of Skeletons, Journal of Human Evolution 9 (1980): 517-549.

\section{Hauser, G. and De Stefano G. 1989.}

Epigenetic Variants of Human Scull, Stuttgart: Schweizerbart-Stuttgart.

\section{Hošovski, E. i Mikić, Ž. 1995,}

First Paleodemographic Results of Antique Viminaciun, Etnoantropološki problemi, sveska 10, (1995): 103-105.

\section{Korać, M. i Golubović, S. 2009}

Viminacium ,Više grobalja 281-530 (kremacija) 268 -550 (inhumacija) T.2, Beograd: Arheološki institut.

\section{Lovričević, A. i Mikić, Ž. 1989}

Atlas osteopatoloških promjena na istorijskim populacijama Jugoslavije, Sarajevo : Svjetlost.

Martin, R. and Saller, K. 1957,

Lehrbuch der Antropologie, Bd. I 519-597.

Ortner, D. J. 2003

Identification of Pathological Conditions in Human Skeletal remains (second edition), Amsterdam, Boston, London, New York, Oxford, Pariz, San Diego, San Francisko, Singapore, Sydney, Tokyo: Academic Press.

\section{Steinbock, R.T. 1976,}

Paleopathological diagnosis and interpretation: Bone diseases in ancient human population, Springfield, Ill:Thomas.

Wolf-Heidegger, G. 1954, Atlas der systematischen Anatomie des Menschen, Bd. 1, Basel-New York.

\section{Zotović, Lj. i Jordović, Č. 1990}

Viminacium nekropola „Više grobalja“, Viminacium knj.1, Beograd:Arheološki institut BeogradZavod za zaštitu spomenika kulture Beograd. 


\section{REZIME \\ DVA SLUČAJA NESPECIFIČNIH INFEKCIJA SA VIMINACIJUMA}

KEY WORDS: VIMINACIUM, RIMSKE NEKROPOLE, BIOFIZIČKA ANTROPOLOGIJA, PALEOPATOLOGIJA, PALEOPATOLOŠKE DIJAGNOZE, PERIOSTITIS, OSTEOMYELITIS.

$\mathrm{Na}$ osnovu paleopatološke analize dva skeleta koja su pronađena na rimskoj nekropoli "Više grobalja" antičkog grada Viminacijuma, potvrđena je nespecifična infekcija koštanog tkiva tipa periostitis. Skelet G-90 pripada muškarcu starom između 15 i 20 godina, visine tela oko $160 \mathrm{~cm}$. Drugi skelet G-2112/D potiče iz grupnog groba koji je sadržao ostatke četiri muške individue, a pripada muškarcu starom oko 40 godina, visine tela oko $168 \mathrm{~cm}$. Poređenjem, može se izvesti zaključak da prvi skelet potiče od individue koja nije prebolela nespecifičnu infekciju koštanog tkiva, dok drugi skelet pripada individui koja je prebolela infekciju i dostigla zrelo životno doba. Ostaje dilema, u kojoj meri otpornost organizma na ovaj tip infekcije zavisi od starosti individue i koji sve činioci, od pobrojanih, mogu biti presudni za nastanak infekcije.
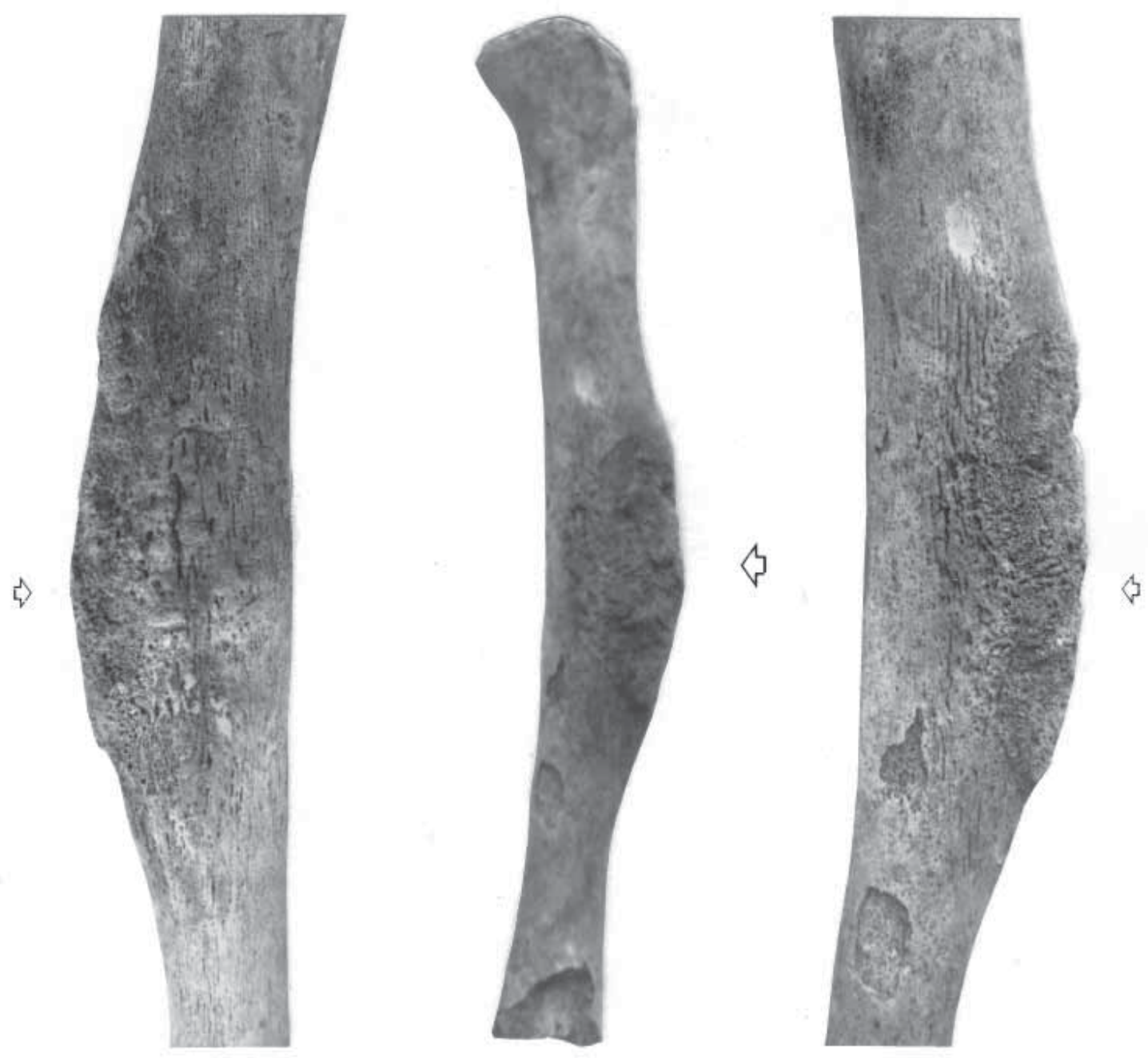

Fig. 1. Više grobalja G-90 

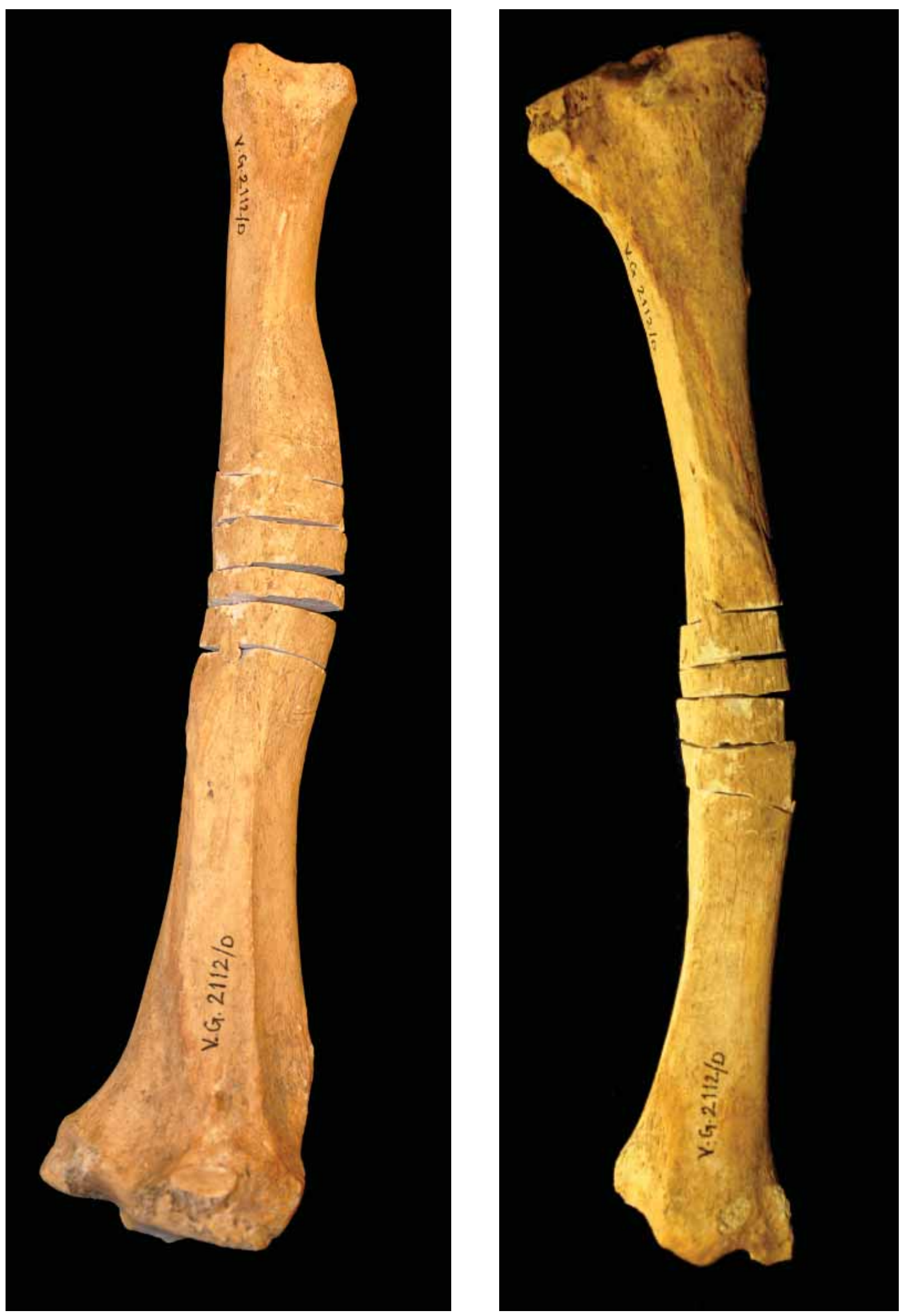

Fig. 2. Više grobalja G-2112 

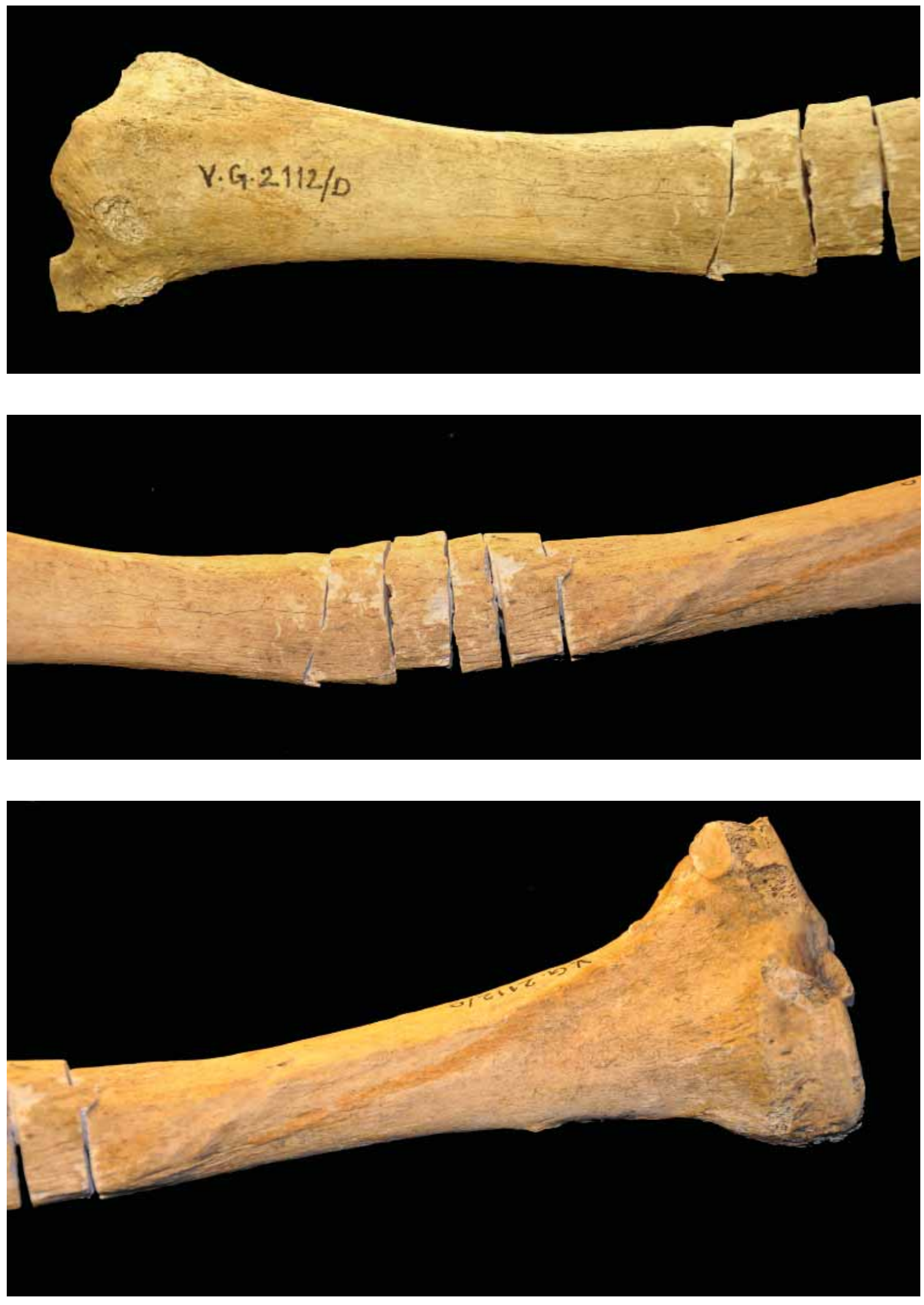

Fig. 3. Više grobalja G-2112 

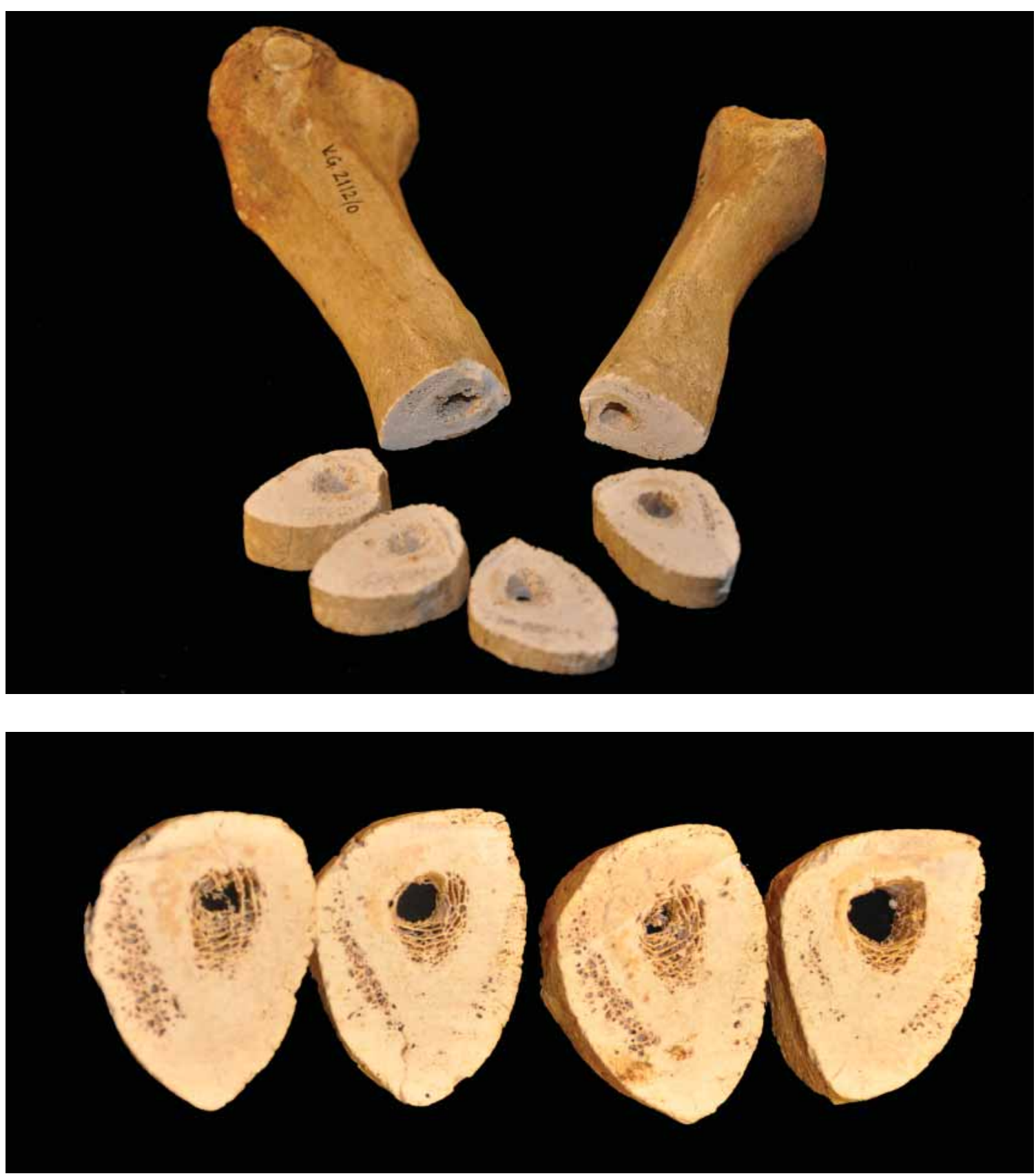

Fig. 4. Više grobalja G-2112 